\title{
Review
}

\section{Post-Ischemic Brain Neurodegeneration in the Form of Alzheimer's Disease Proteinopathy: Possible Therapeutic Role of Curcumin}

\author{
Ryszard Pluta ${ }^{1, *} \mathbb{0}$, Wanda Furmaga-Jabłońska ${ }^{2}$, Sławomir Januszewski ${ }^{1}$ and Stanisław J. Czuczwar ${ }^{3}$ \\ 1 Laboratory of Ischemic and Neurodegenerative Brain Research, Mossakowski Medical Research Institute, \\ Polish Academy of Sciences, 02-106 Warsaw, Poland; sjanuszewski@imdik.pan.pl \\ 2 Department of Neonate and Infant Pathology, Medical University of Lublin, 20-093 Lublin, Poland; \\ wm.jablonska@gmail.com \\ 3 Department of Pathophysiology, Medical University of Lublin, 20-090 Lublin, Poland; \\ stanislaw.czuczwar@umlub.pl \\ * Correspondence: pluta@imdik.pan.pl; Tel.: +48-22-6086-540
}

check for updates

Citation: Pluta, R.;

Furmaga-Jabłońska, W.; Januszewski, S.; Czuczwar, S.J. Post-Ischemic Brain Neurodegeneration in the Form of Alzheimer's Disease Proteinopathy: Possible Therapeutic Role of

Curcumin. Nutrients 2022, 14, 248. https://doi.org/10.3390/nu14020248

Academic Editor: Maria

Antonietta Panaro

Received: 18 December 2021

Accepted: 3 January 2022

Published: 7 January 2022

Publisher's Note: MDPI stays neutral with regard to jurisdictional claims in published maps and institutional affiliations.

Copyright: (C) 2022 by the authors. Licensee MDPI, Basel, Switzerland. This article is an open access article distributed under the terms and conditions of the Creative Commons Attribution (CC BY) license (https:// creativecommons.org/licenses/by/ $4.0 /)$.

\begin{abstract}
For thousands of years, mankind has been using plant extracts or plants themselves as medicinal herbs. Currently, there is a great deal of public interest in naturally occurring medicinal substances that are virtually non-toxic, readily available, and have an impact on well-being and health. It has been noted that dietary curcumin is one of the regulators that may positively influence changes in the brain after ischemia. Curcumin is a natural polyphenolic compound with pleiotropic biological properties. The observed death of pyramidal neurons in the CA1 region of the hippocampus and its atrophy are considered to be typical changes for post-ischemic brain neurodegeneration and for Alzheimer's disease. Additionally, it has been shown that one of the potential mechanisms of severe neuronal death is the accumulation of neurotoxic amyloid and dysfunctional tau protein after cerebral ischemia. Post-ischemic studies of human and animal brains have shown the presence of amyloid plaques and neurofibrillary tangles. The significant therapeutic feature of curcumin is that it can affect the aging-related cellular proteins, i.e., amyloid and tau protein, preventing their aggregation and insolubility after ischemia. Curcumin also decreases the neurotoxicity of amyloid and tau protein by affecting their structure. Studies in animal models of cerebral ischemia have shown that curcumin reduces infarct volume, brain edema, blood-brain barrier permeability, apoptosis, neuroinflammation, glutamate neurotoxicity, inhibits autophagy and oxidative stress, and improves neurological and behavioral deficits. The available data suggest that curcumin may be a new therapeutic substance in both regenerative medicine and the treatment of neurodegenerative disorders such as post-ischemic neurodegeneration.
\end{abstract}

Keywords: brain ischemia; neurodegeneration; curcumin; neuroprotection; amyloid; tau protein; dementia

\section{Introduction}

Today ischemic stroke is a huge and growing health challenge in the world. In developed and developing countries, post-ischemic brain neurodegeneration is becoming more common in view of the progressive aging of the world's population. Ischemiareperfusion brain neurodegeneration in the human population is the third cause of disability, second most common cause of dementia, and second cause of death worldwide, and may soon be the leading cause of dementia [1-5]. Eighty-four percent of ischemic stroke patients in developing countries die within three years after stroke, compared with $16 \%$ in developed countries [6]. In the population of 1 million annually, 2.4 thousand people will have an ischemic stroke and less than $50 \%$ of them will be independent a year later [5-7]. The epidemiological data show that annually about 17 million patients suffer from various types of cerebral ischemia in the world, and 6 million of them die each year as a result of brain 
ischemia $[4,5,8]$. Currently, it is estimated that the number of people after brain ischemia around the world reaches about 33 million [4,5,8]. According to new prognosis, the number of ischemic stroke patients in the world will increase to 77 million in 2030 [5,8]. In 2010, the annual cost of treating and caring for ischemic stroke patients in Europe was estimated at around $€ 64$ billion [4]. In the UK, treating stroke and loss of productivity result in a social cost of $£ 8.9$ billion per year, with care costs accounting for about $5 \%$ of the total cost of the National Healthcare System [9]. Post-stroke neurological deficits are usually not the main problem, but the gradual, progressive cognitive decline that is associated with increased care of these patients is becoming a problem. In ischemic stroke survivors, the incidence of dementia after the first ischemic episode is estimated to be around $10 \%$ and around $41 \%$ after the next ischemic stroke $[4,5]$. In long-term studies of dementia after ischemic stroke, the estimated development of dementia was approximately $48 \%$ during 25 years of survival $[4,8]$. When the ischemic stroke trend continues, approximately 12 million patients will die by 2030, 70 million patients will be stroke survivors, and more than 200 million years of life with a disability will be recorded worldwide each year $[4,8]$.

It is now well known that post-ischemic brain neurodegeneration is caused by a set of genetic and proteomic changes that lead to neuronal death in an amyloid- and tau protein-dependent manner, with progressive inflammation resulting in brain atrophy with the development of full-blown Alzheimer's disease dementia [4,10,11]. Research indicates that after ischemia the brain can develop the typical neurodegeneration of Alzheimer's disease [3,4,11-22]. First, post-ischemic brain damage causes selective neuronal death in the hippocampus typical of Alzheimer's disease with progressive brain atrophy [23-28]. Second, neuroinflammatory changes play a key role in the progression of post-ischemic brain neurodegeneration $[10,12]$. Third, evidence shows that cerebral ischemia in animals and humans induces the production and accumulation of amyloid in the form of amyloid plaques [26,29-34]. Fourth, research indicates that hyperphosphorylation of the tau protein with the final formation of neurofibrillary tangles also plays a key role in the development of post-ischemic brain neurodegeneration as in Alzheimer's disease [35-54]. Fifth, dysfunction of the autophagy, mitophagy, and apoptosis genes is involved in post-ischemic neurodegeneration, as in Alzheimer's disease [55-57]. Sixth, cerebral ischemia is believed to be a causative factor in Alzheimer's disease development [23]. It is also believed that the signaling pathways generated by amyloid and tau protein after cerebral ischemia play a decisive role in the development of irreversible neurodegeneration [26,29,35,53,54,58-60].

There are no therapies to prevent progressive changes from cerebral ischemia and/ or to delay or stop post-ischemic neurodegeneration. In the absence of translational experimental post-ischemic therapies in animals for clinical use [61], the emphasis is on reducing the neurotoxic effects of amyloid and tau protein on post-ischemic neurons to prevent brain neurodegeneration with dementia of Alzheimer's disease-type. This work also focuses on the neuroprotective effects of curcumin's pleiotropic properties on the ischemic brain.

\section{Search Criteria and Data Collection}

Published scientific papers on the use of curcumin have been screened for in vivo, in vitro, experimental and clinical studies, interactions between curcumin and the gut microbiota and vice versa, and side effects. Searches were performed digitally using databases, including PubMed, SCOPUS, MEDLINE, Science Direct, and Google Scholar to identify peer-reviewed original articles and reviews over the past two decades (1 January 20011 July 2021). The search strategy was carried out using the following key words: "curcumin and brain ischemia", "brain ischemia and curcumin", "curcumin and stroke", stroke and curcumin", "curcumin, neuroprotection, and brain ischemia", "curcumin and amyloid", "curcumin and tau protein", "curcumin and gut microbiota", "gut microbiota and curcumin". A total of 1201 original papers and reviews were found, and 150 publications closely related to the subject of the review were used. 


\section{Curcumin}

The favorable effects of many miscellaneous substances have been discovered through the regular consumption of plants and fruits as food. This is also the case with curcumin, whose action has been known for years in eastern countries such as India and China. Curcumin is widely used in Chinese and Indian cuisines, but has only recently been recognized as a natural remedy with proven pharmacological properties. It was chemically isolated for the first time over 200 years ago, and its structure was characterized in 1910 [62]. Curcumin is a phytopolylphenol pigment (1E,6E)-1,7-bis(4-hydroxy-3-methoxyphenyl)hepta1,6-diene-3,5-dione) obtained from the Curcuma longa plant (Figure 1). Curcuma longa is an herbaceous perennial plant with oblong palm-like roots and tubers that grows spontaneously in Africa and South Asia, in regions with tropical climates with high rainfall. The world leader in the production of curcumin is India. Curcumin is yellow in color and is used for health, as a food preservative, but also as a fabric dye.

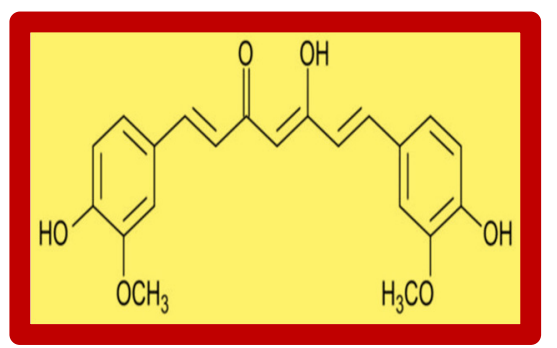

Figure 1. Chemical structure of curcumin.

Curcuma longa, commonly known as turmeric and one of its biologically active ingredients, curcumin, is enjoying increasing clinical interest worldwide due to growing evidence of therapeutic potential resulting from numerous observations that include antioxidant, anti-inflammatory, and neurotrophic effects [63]. Curcumin is commonly used as a healing herb to aid digestion and as a culinary seasoning. With health care professionals using curcumin for a variety of clinical uses, as well as increasing interest in turmeric among laypeople, it fuels the global curcumin market. Clinical studies are heterogeneous due to the use of various forms of curcumin, turmeric essential oil, a mixture of curcuminoids, turmeric extracts, or powdered turmeric rhizome. Thus, curcumin has shown some potential in disorders, such as dermatological, gastrointestinal and neurological diseases, diabetes, cancer, and gut microbiota control [64].

\section{Curcumin and Neuroprotection}

Following experimental local brain ischemia, curcumin reduced both infarct volume and brain edema, prevented blood-brain barrier permeability, and improved neurological outcomes (Table 1) [65-78]. Curcumin had a beneficial effect on locomotor, motor, and sensory functions, as well as cognitive deficits (Table 1) [67,71,72,76,78-80]. Curcumin reduced neuronal apoptosis by increasing $\mathrm{Bcl} 2$ protein levels and by down-regulating caspase- 3 mRNA and ultimately stimulating neurogenesis (Table 1) (Figure 2) [68,76,77,79-86]. Curcumin improved cerebral blood flow in the brain after ischemia by preventing neutrophil adhesion to the cerebral circulation, resulting in improved microcirculation in the brain (Table 1) [70,72]. In addition, it reduced astrogliosis and post-ischemic neuroinflammation (Table 1) $[66,69,72,79]$. Supplementation with curcumin reduced the inflammation of the nervous system by reducing tumor necrosis factor $\alpha$, interleukin 6 , and inducible nitric oxide synthase, and decreased the activity of autophagy through PI3K/Akt/mTOR [76,78,83,85]. 
Table 1. Protective action of curcumin in post-ischemic neurodegeneration of the brain.

\begin{tabular}{ccc}
\hline Brain Ischemia in Animals & Benefits & References \\
\hline Rat, mouse & $\begin{array}{c}\text { Reduction in infarct size and } \\
\text { brain edema }\end{array}$ & {$[65-67,69,71,72,76,78]$} \\
Mouse & $\begin{array}{c}\text { Reduction in the permeability of } \\
\text { the blood-brain barrier }\end{array}$ & {$[66,69]$} \\
\hline Rat, gerbil, & Decreasing apoptosis & {$[76-81]$} \\
\hline Rat, mouse & $\begin{array}{c}\text { Improvement of } \\
\text { microcirculation in the brain }\end{array}$ & {$[70,72]$} \\
\hline Gerbil, mouse & $\begin{array}{c}\text { Reduced neuroinflammation } \\
\text { Attenuation of glutamate } \\
\text { neurotoxicity }\end{array}$ & {$[72,79]$} \\
\hline Rat & $\begin{array}{c}\text { Mutual inhibition of } \\
\text { hypoxia-inducible factor-1 } \alpha \\
\text { and autophagy }\end{array}$ & {$[82]$} \\
\hline Rat & Inhibition of oxidative stress & {$[86,78,83]$} \\
\hline Rat & $\begin{array}{c}\text { Stimulation of neurogenesis } \\
\text { Rat, gerbil, mouse }\end{array}$ & $\begin{array}{c}\text { Improving neurological and } \\
\text { behavioral deficits }\end{array}$ \\
\hline
\end{tabular}

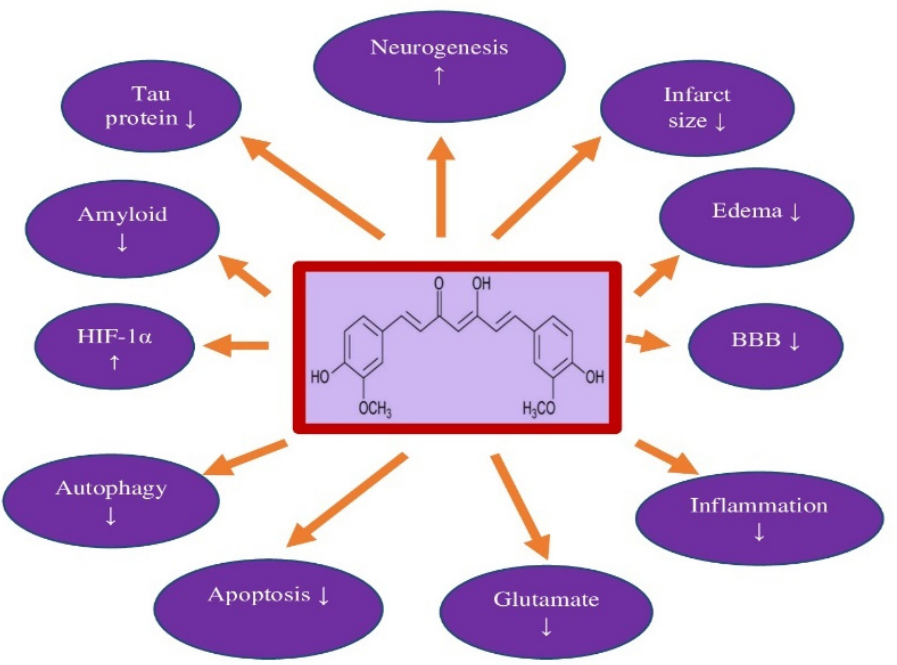

Figure 2. Protective influence of curcumin on post-ischemic brain neurodegeneration phenomena. In a rectangle-structure of curcumin, $\downarrow$-decrease, $\uparrow$-increase, BBB-blood brain barrier, HIF- $1 \alpha$ hypoxia-inducible factor- $1 \alpha$.

Curcumin is also protective in rats with spontaneous hypertension prone to stroke, delaying the onset of stroke and increasing survival by improving vascular endothelial function [87]. These effects are most likely due to the increase in the presence of proteins from the family of mitochondrial anion carriers and the curcumin-induced regulation of the production of reactive oxygen species in the mitochondria [87]. These observations were also confirmed in the HUVEC cell model, using $\mathrm{H}_{2} \mathrm{O}_{2}$ to induce oxidative stress in vitro, which was alleviated by curcumin treatment [87]. Data similar to those obtained in the rat were also demonstrated in a mouse model of focal cerebral ischemia, in which curcumin treatment reduced the volume of cerebral infarction and neuronal apoptosis and in vitro on N2a cells, possibly by limiting mitochondrial dysfunction [88]. In parallel, curcumin influenced neurological deficits and the integrity of the ischemic blood-brain barrier, decreased brain cortex infarction, mortality, and apoptosis of neurons after cerebral 
ischemia $[82,89,90]$. Moreover, curcumin reduced the neurotoxicity of glutamate in the postischemic hippocampus (Table 1) [82]. In a new study, curcumin protected ischemic neuronal cells from apoptotic death through the neuroprotective effects of curcumin associated with the reciprocal inhibition of hypoxia-inducible factor- $1 \alpha$ and autophagy (Table 1) [83].

\section{Curcumin and Amyloid}

Amyloid is a product of the metabolism of the amyloid protein precursor. The production of amyloid is catalyzed by two enzymes, $\beta$ - and $\gamma$-secretase. It has been suggested that after ischemia, the development of inflammation increases the production of amyloid via increased activity of $\beta$-secretase [91]. Curcumin, by inhibiting the action of $\beta$-secretase, thus reduced the production of amyloid [91-93]. In addition, curcumin inhibits the maturation of the amyloid protein precursor resulting in a reduction in amyloid in brain tissue $[94,95]$. Curcumin may also affect amyloid production by inhibiting glycogen synthase kinase- $3 \beta$ mediated presenilin 1 activity, which is one of the important components of $\gamma$-secretase [96]. It has been documented that the generation of amyloid can be limited by the metal chelation phenomenon [97] and the decline in $\beta$-secretase activation by proinflammatory factors $[58,93]$. Additionally, it was presented that curcumin significantly increased the retention of the immature amyloid protein precursor in the reticulum [58]. In addition, it has been suggested that curcumin may affect the endocytosis of the amyloid protein precursor [95].

Experimental results have shown that curcumin binds to $\beta$-amyloid peptide 1-42 fibrils [98]. Curcumin has a strong inhibitory effect on amyloid aggregates in vitro, indicating that it is one of the most promising anti-amyloid substances [99-102]. In vivo and in vitro studies have revealed that curcumin has a dose-dependent effect on the inhibition of fibril development of the amyloid peptide 1-42 and 1-40, with an EC50 of 0.09-0.63 $\mu \mathrm{M}[92,103]$. Several studies have presented that curcumin can inhibit the deposition of amyloid peptide $1-42$ and $1-40$ as oligomers, as well as the development of their fibril form $[92,103,104]$. Curcumin prevents the toxicity of the $\beta$-amyloid peptide 1-40 and inhibits the process of its aggregation [105]. The above results indicate that curcumin does not directly inhibit the development of amyloid fibrils, but rather enriches the amount of soluble oligomers and prefibrillar aggregates that do not have neurotoxic properties. The neuroprotective effect associated with curcumin is manifested in a decrease in the permeability of the cell membrane caused by amyloid. Furthermore, curcumin exerted a neuroprotective effect on amyloid-triggered toxicity by at least two compatible processes, modifying amyloid aggregation to develop non-toxic aggregates and ameliorating amyloid-induced neurotoxicity, possibly by a non-specific mechanism [105]. It was found that gold nanoparticles loaded with curcumin inhibited the aggregation of the $\mathrm{N}$-terminus of amyloid and were able to dissolve its aggregates [106]. Another study provided evidence that curcumin disorganized amyloid fibrils as a result of structural changes at the salt bridge site near the C-terminus of amyloid [107]. Other studies have documented that curcumin also inhibits the development of amyloid oligomers and fibrils, binds amyloid plaques, destroys existing amyloid plaques, and decreases amyloid level and its neurotoxicity in vivo $[92,105,108]$. In contrast, systemic curcumin supplementation to transgenic mice for one week removed and reduced the number of amyloid plaques [108]. Curcumin also reversed structural alterations in dendrites. It follows from the above that curcumin reversed the pathological effects of amyloid and its associated toxicity in transgenic mice [108].

Post-ischemic brain amyloid level depends on the balance between brain amyloid production, clearance, and from serum influx. Thus, disruption of the clearance pathways of amyloid from the brain promotes an increase in its level in the brain parenchyma. Several possible mechanisms for removing amyloid from brain have been identified, including transport of amyloid by lipoprotein receptor related protein-1 across the blood-brain barrier into plasma, subsequent breakdown of amyloid by specialized enzymes, and also through the immune system [109]. Curcumin works similar to an amyloid vaccine by binding to amyloid, allowing it to be cleared from the brain parenchyma by promoting receptor medi- 
ated amyloid clearance $[92,93]$. In addition, curcumin may reduce amyloid influx into the brain parenchyma from blood by blocking the receptor for advanced glycation end-products at the blood-brain barrier and by increasing the enzymatic metabolism of amyloid [92,93]. Curcumin has phagocytic-stimulating properties and increases the number of phagocytic cells around amyloid plaques and also around human brain amyloid plaques exposed to rodent microglia after death [110-112]. Curcumin has been documented to induce amyloid phagocytosis through microglia activation and enzymatic metabolism [112]. Curcumin also stimulates B lymphocytes to produce anti-amyloid antibodies. In summary, curcumin simultaneously blocks the flow of amyloid from the serum into the brain parenchyma and increases its flow from the brain tissue into the blood.

\section{Curcumin and Tau Protein}

Neural cells are rich in tau protein, which is used to stabilize microtubules. Another important pathology associated with folding proteins in the brain after ischemia in humans and animals are neurofibrillary tangles, which are inherently associated with excessive hyperphosphorylation of the tau protein [35,39,49,53,113-115]. Hyperphosphorylated tau protein, among other things, triggers oxidative stress, causes mitochondrial dysfunction, and ultimately contributes to the progressive development of brain neurodegeneration [116]. The hyperphosphorylation and accumulation of tau protein in the form of neurofibrillary tangles are regulated by several tau protein kinases, the most common of them being glycogen synthase kinase- $3 \beta$ and the mitogen-activated protein kinase [39,54,96,117]. Common tau protein kinases that pathologically phosphorylate the tau protein are extracellular signal-regulated kinase 2, cyclin-dependent kinase 5, S6 kinase, SAD kinase, microtubule affinity regulating kinase, protein kinase A, calcium/calmodulin II dependent protein kinase, and kinases Fyn and c-Abl. Therefore, it is believed that the effect of curcumin on tau protein kinases is an activity to prevent or slow down [118]. Curcumin has been shown to bind to neurofibrillary tangles in the brains of animals with experimental Alzheimer's disease, resulting in inhibition of the action of prion proteins [118]. In vitro studies have shown that curcumin inhibits the accumulation of hyperphosphorylated tau protein and disintegrates its fibers [119]. Curcumin also inhibits glycogen synthase kinase-3 $\beta$ activity and reduces tau protein hyperphosphorylated oligomerization and tau protein dimmer development in tau protein transgenic animals $[96,120]$. In addition, oral curcumin supplementation with docosahexaenoic acid reduced tau protein hyperphosphorylation by inhibiting the activity of C-Jun N-terminal kinase and insulin receptor 1 substrate [120].

\section{Curcumin Bioavailability and Gut Microbiome}

There are three compelling reasons why the therapeutic potential of curcumin has yet to be realized. The first is low oral bioavailability, mainly due to its rapid metabolism, limited absorption, and rapid systemic elimination. Second, curcumin is poorly soluble in water, around $11 \mathrm{ng} / \mathrm{mL}$, and is highly metabolized in the body [85]. Third, when curcumin is administered orally, most of it is excreted in feces due to poor absorption in the gastrointestinal tract, moreover, curcumin is inactivated in the intestinal mucosa by glucuronidation. Curcumin then undergoes reduction in the first pass effect to hexahydrocurcumin, followed by conjugation with sulphates and glucuronides in the liver [121,122], and is finally excreted in urine [85]. Pharmacokinetic studies in rodents and humans showed that the highest blood levels achieved after oral administration were $0.051 \mu \mathrm{g} / \mathrm{mL}$ with $12 \mathrm{~g}$ of curcumin in humans, $1.35 \mu \mathrm{g} / \mathrm{mL}$ with $2 \mathrm{~g} / \mathrm{kg}$ in the rat, and $0.22 \mu \mathrm{g} / \mathrm{mL}$ with $1 \mathrm{~g} / \mathrm{kg}$ in mice [84]. Orally administered curcumin has been shown to have a bioavailability of $1 \%$ lower than after intraperitoneal or intravenous administration [123,124]. Curcumin appears in the blood $15 \mathrm{~min}$ after intraperitoneal administration, $45 \mathrm{~min}$ later it can be found in the liver, spleen, intestines, kidneys, and brain because curcumin crosses the blood-brain barrier [123,124]. In a rodent model, the presence of the l-piperoylpiperidine alkaloid produced from black pepper fruit, an inhibitor of uridine-5'-diphosphoglucuronosyl transferase, increases the oral bioavailability of curcumin by up to $154 \%$ [123] and results in the presence of curcumin 
in the brain notably up to $96 \mathrm{~h}$ after administration [124]. The bioavailability of curcumin can be increased by administering its derivatives which exhibit enhanced biological activity and improved pharmacokinetics, one example being dimethoxycurcumin, which has a higher level of metabolic stability [125].

The problem of the low bioavailability of curcumin is currently under discussion. Despite the low bioavailability of curcumin, its use is not ruled out, as it has beneficial effects even in small doses [126,127]. The poor bioavailability of curcumin is associated with limited absorption and rapid metabolism, which results in rapid elimination from the body. It should be added that the high concentration of curcumin causes side effects related to its action [127]. In the human body, the metabolism of curcumin takes place mainly in the small intestine and liver $[127,128]$. The main products of curcumin metabolism are glucuronides $[127,129,130]$. However, the lysosomal enzyme responsible for the deconjugation of glucuronides is present in the organisms, i.e., $\beta$-glucuronidase, and one of its substrates is curcumin glucuronide [131,132]. $\beta$-glucuronidase activity increases in inflammation [133], and the development of inflammation is associated with post-ischemic brain neurodegeneration $[10,12,134]$. It should be assumed that the local concentrations of curcumin may differ from those found in the blood [135]. It cannot be excluded that the inflammation associated with cerebral ischemia is responsible for the increased concentration of unmetabolized curcumin in the tissues or organs of the affected individuals. The glucuronidation of curcumin is just one of many factors affecting its bioavailability. Blood and tissue levels are affected by other factors, such as low food levels of curcumin and its interactions with other food ingredients. Curcumin is able to pass the blood-brain barrier but the permeability for the curcumin by the barrier is limited [92,127,136,137]. Although the concentration in the brain parenchyma is lower than in the blood, curcumin alleviates inflammation in the nervous system. It is currently suggested that the actual activity of curcumin in the body is not direct, but is mediated through the gut microflora $[138,139]$. In addition, there is evidence that gut bacteria produce large amounts of $\beta$-glucuronidase, which can raise curcumin levels [140]. This suggests that the gut microflora may control curcumin metabolism and bioavailability in the body. The gut microbiome changes throughout life [141] and progressive aging is associated with reduced microbial diversity in composition, quantity and quality, and the occurrence of cerebral ischemia [13,142-145]. There are experimental indications that curcumin may modulate the composition of the gut microbes, including microbial diversity [86,146-149]. It is believed that by modulating the gut microbiome, curcumin can reduce some of the negative consequences of post-ischemic neurodegeneration in the brain, for example by slowing it down. In conclusion, curcumin, by influencing the gut microflora, can positively affect some pathological changes. The gut microflora, through its ability to metabolize curcumin, can regulate its bioavailability.

\section{Conclusions}

Injury and death of neuronal cells, with the accumulation of diffuse amyloid and senile plaques, the development of neurofibrillary tangles, as well as neurological deficits with the development of full-blown dementia are the main phenomena in post-ischemic brain neurodegeneration in animals and humans. Due to the pleiotropic action of curcumin, such as anti-inflammatory, anti-oxidant, anti-amyloid, anti-dysfunctional tau protein, and anti-dementia properties, curcumin is a promising candidate for the prevention and therapy of post-ischemic brain neurodegeneration (Figures 2-4). In addition, it is a safe substance, approved in the Europe and US as a pro-health substance, commercially available, and inexpensive. Recapitulating, the information available in this article about the pharmacological activity of curcumin provides significant evidence for the potential clinical utility of curcumin in the therapy of neurodegenerative phenomena with accumulation of folding proteins, such as amyloid and tau protein following ischemia (Figure 2). 


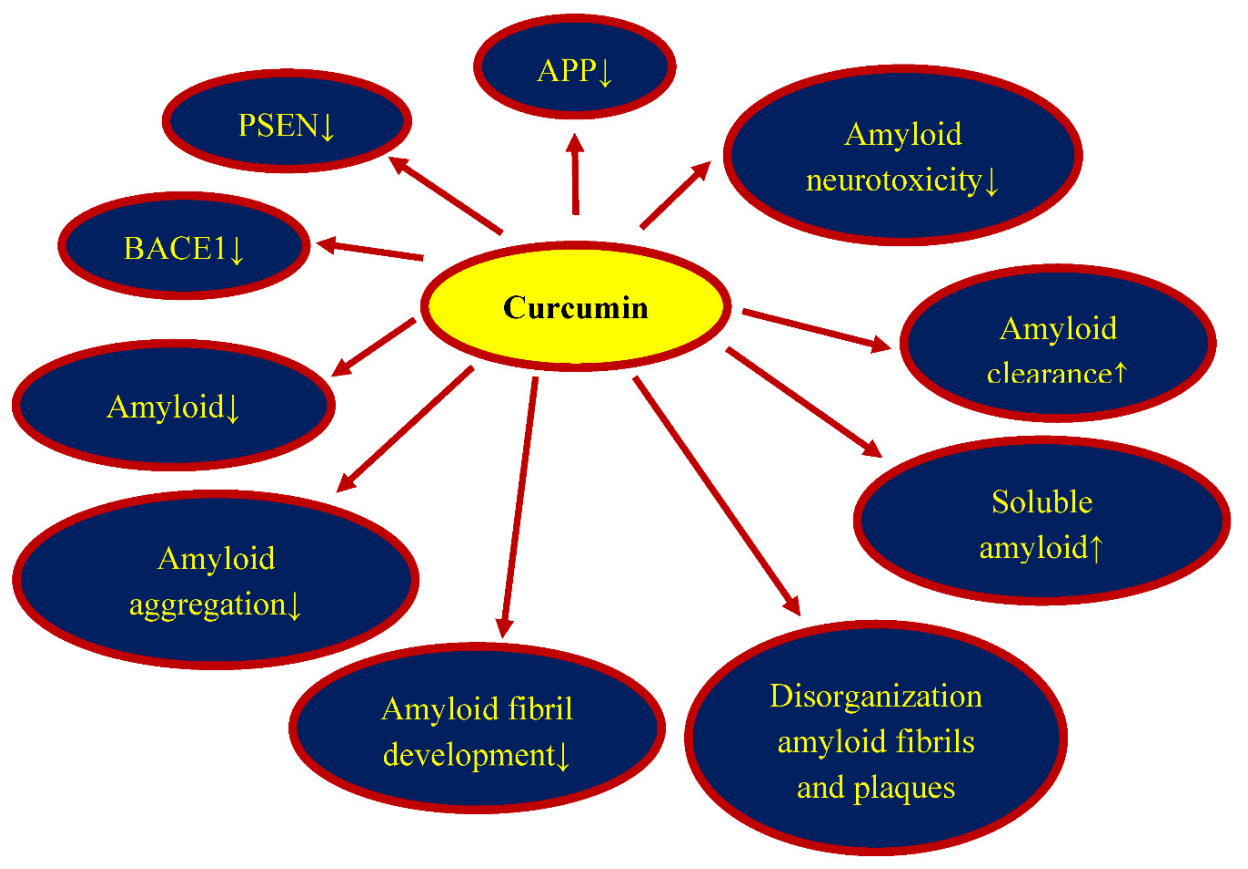

Figure 3. Protective effects of curcumin on post-ischemic amyloid pathology. APP-amyloid protein precursor, PSEN1-presenilin 1, BACE1- $\beta$-secretase, $\downarrow$-decrease, $\uparrow$-increase.

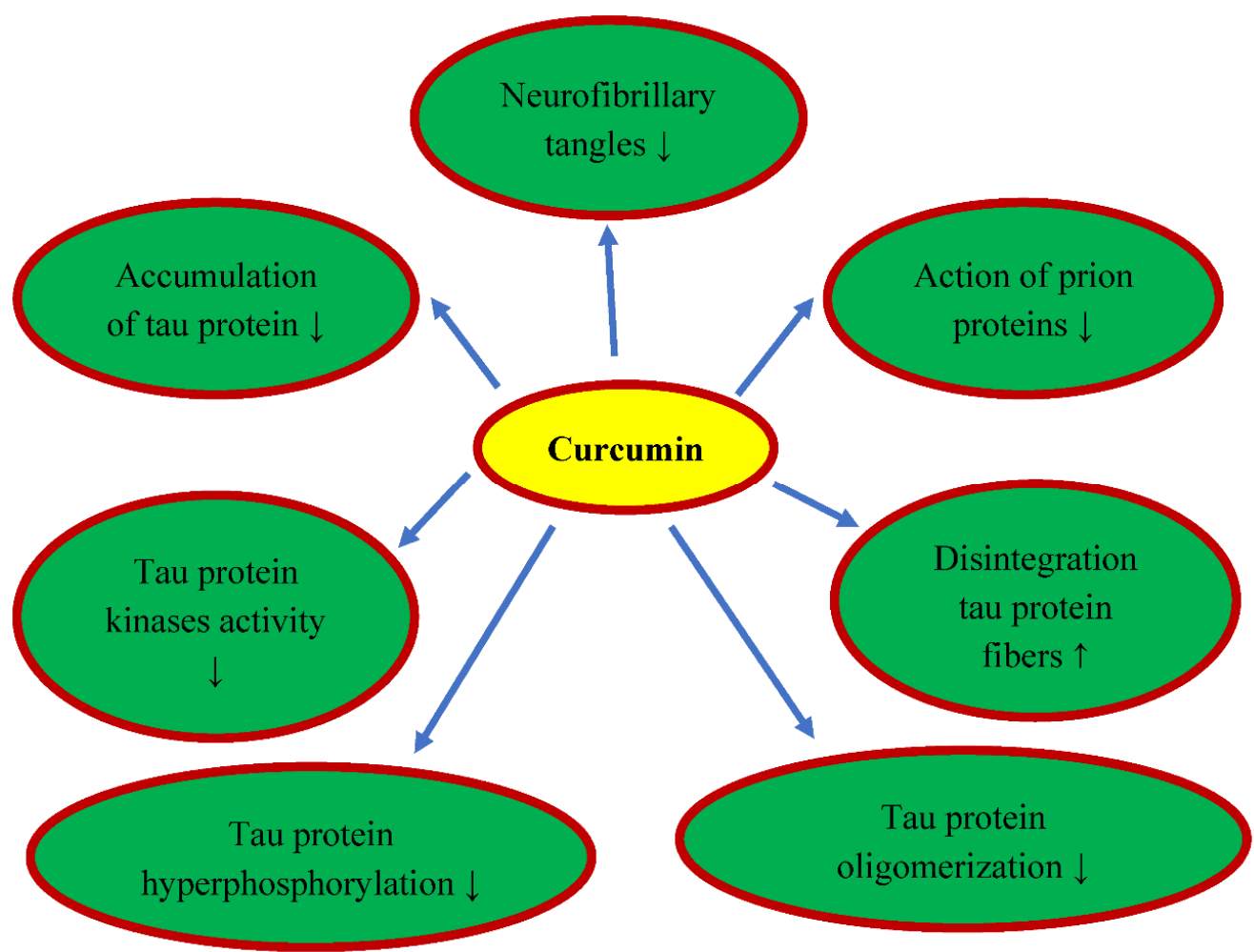

Figure 4. Protective effects of curcumin on post-ischemic tau protein dysfunction. $\downarrow$-decrease, $\uparrow$-increase.

In this review, we presented the neuroprotective effects of curcumin in post-ischemic brain neurodegeneration. Evidence shows neuroprotective, neurological, and cognitive positive effects of curcumin after ischemia-reperfusion brain injury (Figure 2). Based on the evidence presented, it seems that curcumin has therapeutic potential through anti-amyloid, anti-tau protein hyperphosphorylation, antioxidant, anti-inflammatory, anti-apoptotic 
effects, and influences autophagy, clearly indicating that curcumin can be used as a neuroprotective agent in post-ischemic neurodegeneration (Figure 2). It is clear that curcumin induces neuroprotection and neurogenesis, and may be a new drug substance in the treatment of aging and neurodegenerative diseases, including neurodegeneration following cerebral ischemia [150]. For this reason, curcumin may be a promising substance to counteract ischemic neurodegeneration in the future. Overall, there is a scientific rationale for the use of curcumin in the prevention and therapy of post-ischemic neurodegeneration. Nevertheless, despite preliminary hard data, prospective studies are needed to further elucidate how curcumin may be protective against ischemic brain injury and how it can be used during treatment of post-ischemic neurodegeneration. In particular, evidence from randomized controlled clinical trials will be helpful.

\section{Outlook}

The data presented in this review show a promising protective effect of curcumin after ischemia-reperfusion brain injury. However, a limited number of investigations after brain ischemia provide evidence of low or very low quality. Since post-ischemic observations have been brief, the long-term effects associated with curcumin use are currently unknown. Future randomized clinical studies are needed to confirm curcumin effectiveness and to provide additional information on some of the unresolved issues, such as how long curcumin can be used. Despite very scarce research, the results of curcumin in treating cerebral ischemia so far appear interesting in preventing the deposition of amyloid plaques and dysfunctional tau protein (Figures 3 and 4). In recent years, curcumin's reputation for pharmacological effects has steadily increased. Due to the fact that curcumin, similar to many other natural molecules, has more than one drug target, it indicates its versatile use and low risk of resistance to therapy. There is no doubt that, due to the preclinical results, the next step must be the study of curcumin in well-designed and controlled clinical trials. Double-blind studies are needed to elucidate the curcumin treatment properties. A definitive explanation of curcumin's healing properties may offer hope for a long-term therapeutic effect. Curcumin has not been approved for clinical use. Low bioavailability is a major limitation on the utility of curcumin in the clinic. We hope that future clinical research will help us better understand the therapeutic potential of curcumin and put this fascinating molecule at the forefront of new neuroprotective therapies.

Author Contributions: Conceptualization, R.P., W.F.-J. and S.J.C.; methodology, S.J.; software, S.J.; validation, R.P., W.F.-J., S.J.C. and S.J.; formal analysis, R.P. and W.F.-J.; investigation, S.J.; resources, S.J.; data curation, R.P. and W.F.-J.; writing-original draft preparation, R.P., W.F.-J. and S.J.C.; writing-review and editing, R.P., S.J.C. and S.J.; visualization, S.J.; supervision, R.P.; project administration, R.P. and S.J.; funding acquisition, R.P., W.F.-J. and S.J.C. All authors have read and agreed to the published version of the manuscript.

Funding: This research received no external funding.

Institutional Review Board Statement: Not applicable.

Informed Consent Statement: Not applicable.

Data Availability Statement: Not applicable.

Acknowledgments: The authors acknowledge the financial support from the following institutions: the Mossakowski Medical Research Institute, Polish Academy of Sciences, Warsaw, Poland (T3-RP), and the Medical University of Lublin, Lublin, Poland (DS 475/21-SJC).

Conflicts of Interest: The authors declare no conflict of interest.

\section{References}

1. Mok, V.C.T.; Lam, B.Y.K.; Wang, Z.; Liu, W.; Au, L.; Leung, E.Y.L.; Chen, S.; Yang, J.; Chu, W.C.W.; Lau, A.Y.L.; et al. Delayed-onset dementia after stroke or transient ischemic attack. Alzheimer's Dement. 2016, 12, 1167-1176. [CrossRef]

2. Portegies, M.L.; Wolters, F.J.; Hofman, A.; Ikram, M.K.; Koudstaal, P.J.; Ikram, M.A. Prestroke vascular pathology and the risk of recurrent stroke and poststroke dementia. Stroke 2016, 47, 2119-2122. [CrossRef] 
3. Kim, J.H.; Lee, Y. Dementia and death after stroke in older adults during a 10-year follow-up: Results from a competing risk model. J. Nutr. Health Aging 2018, 22, 297-301. [CrossRef]

4. Pluta, R.; Ułamek-Kozioł, M.; Januszewski, S.; Czuczwar, S.J. Amyloid pathology in the brain after ischemia. Folia Neuropathol. 2019, 57, 220-226. [CrossRef]

5. Goulay, R.; Romo, L.M.; Hol, E.M.; Dijkhuizen, R.M. From stroke to dementia: A comprehensive review exposing tight interactions between stroke and amyloid- $\beta$ formation. Transl. Stroke Res. 2020, 11, 601-614. [CrossRef] [PubMed]

6. Johnson, W.; Onuma, O.; Owolabi, M.; Sachdev, S. Stroke: A global response is needed. Bull. World Health Organ 2016, 94 , 634-634A. [CrossRef] [PubMed]

7. Pluta, R.; Bogucka-Kocka, A.; Ułamek-Kozioł, M.; Furmaga-Jabłońska, W.; Januszewski, S.; Brzozowska, J.; Jabłoński, M.; Kocki, J. Neurogenesis and neuroprotection in postischemic brain neurodegeneration with Alzheimer phenotype: Is there a role for curcumin? Folia Neuropathol. 2015, 53, 89-99. [CrossRef]

8. Bejot, Y.; Daubail, B.; Giroud, M. Epidemiology of stroke and transient ischemic attacks: Current knowledge and perspectives. Rev. Neurol. 2016, 172, 59-68. [CrossRef]

9. Murphy, S.J.X.; Werring, D.J. Stroke: Causes and clinical features. Medicine 2020, 48, 9. [CrossRef] [PubMed]

10. Sekeljic, V.; Bataveljic, D.; Stamenkovic, S.; Ułamek, M.; Jabłoński, M.; Radenovic, L.; Pluta, R.; Andjus, P.R. Cellular markers of neuroinflammation and neurogenesis after ischemic brain injury in the long-term survival rat model. Brain Struct. Funct. 2012, 217, 411-420. [CrossRef] [PubMed]

11. Pluta, R. Brain ischemia as a bridge to Alzheimer's disease. Neural Regen. Res. 2022, 17, 791-792. [CrossRef] [PubMed]

12. Radenovic, L.; Nenadic, M.; Ułamek-Kozioł, M.; Januszewski, S.; Czuczwar, S.J.; Andjus, P.R.; Pluta, R. Heterogeneity in brain distribution of activated microglia and astrocytes in a rat ischemic model of Alzheimer's disease after 2 years of survival. Aging 2020, 12, 12251-12267. [CrossRef] [PubMed]

13. Pluta, R.; Januszewski, S.; Czuczwar, S.J. The role of gut microbiota in an ischemic stroke. Int. J. Mol. Sci. 2021, 22, 915. [CrossRef] [PubMed]

14. Salminen, A.; Kauppinen, A.; Kaarniranta, K. Hypoxia/ischemia activate processing of amyloid precursor protein: Impact of vascular dysfunction in the pathogenesis of Alzheimer's disease. J. Neurochem. 2017, 140, 536-549. [CrossRef]

15. Pluta, R. Brain Ischemia: Alzheimer's Disease Mechanisms; Nova Science Publishers, Inc.: New York, NY, USA, 2019 ; p. 311.

16. De la Tremblaye, P.B.; Plamondon, H. Impaired conditioned emotional response and object recognition are concomitant to neuronal damage in the amygdale and perirhinal cortex in middle-aged ischemic rats. Behav. Brain Res. 2011, 219, 227-233. [CrossRef] [PubMed]

17. Kiryk, A.; Pluta, R.; Figiel, I.; Mikosz, M.; Ułamek, M.; Niewiadomska, G.; Jabłoński, M.; Kaczmarek, L. Transient brain ischemia due to cardiac arrest causes irreversible long-lasting cognitive injury. Behav. Brain Res. 2011, 219, 1-7. [CrossRef]

18. Li, J.; Wang, Y.J.; Zhang, M.; Fang, C.Q.; Zhou, H.D. Cerebral ischemia aggravates cognitive impairment in a rat model of Alzheimer's disease. Life Sci. 2011, 89, 86-92. [CrossRef]

19. Brainin, M.; Tuomilehto, J.; Heiss, W.D.; Bornstein, N.M.; Bath, P.M.; Teuschl, Y.; Richard, E.; Guekht, A.; Quinn, T. Post Stroke Cognition Study Group. Post-stroke cognitive decline: An update and perspectives for clinical research. Eur. J. Neurol. 2015, 22, 229-238. [CrossRef]

20. Cohan, C.H.; Neumann, J.T.; Dave, K.R.; Alekseyenko, A.; Binkert, M.; Stransky, K.; Lin, H.W.; Barnes, C.A.; Wright, C.B.; Perez-Pinzon, M.A. Effect of cardiac arrest on cognitive impairment and hippocampal plasticity in middle-aged rats. PLoS ONE 2015, 10, e0124918.

21. Surawan, J.; Areemit, S.; Tiamkao, S.; Sirithanawuthichai, T.; Saensak, S. Risk factors associated with post-stroke dementia: A systematic review and meta-analysis. Neurol. Int. 2017, 9, 7216. [CrossRef]

22. Bivard, A.; Lillicrap, T.; Maréchal, B.; Garcia-Esperon, C.; Holliday, E.; Krishnamurthy, V.; Levi, C.R.; Parsons, M. Transient ischemic attack results in delayed brain atrophy and cognitive decline. Stroke 2018, 49, 384-390. [CrossRef] [PubMed]

23. Snowdon, D.A.; Greiner, L.H.; Mortimer, J.A.; Riley, K.P.; Greiner, P.A.; Markesbery, W.R. Brain infarction and the clinical expression of Alzheimer disease: The Nun Study. JAMA 1997, 277, 813-817. [CrossRef]

24. Hossmann, K.A.; Schmidt-Kastner, R.; Ophoff, B.G. Recovery of integrative central nervous function after one hour global cerebro-circulatory arrest in normothermic cat. J. Neurol. Sci. 1987, 77, 305-320. [CrossRef]

25. Pluta, R. The role of apolipoprotein $\mathrm{E}$ in the deposition of $\beta$-amyloid peptide during ischemia-reperfusion brain injury. A model of early Alzheimer's disease. Ann. N. Y. Acad. Sci. 2000, 903, 324-334. [CrossRef]

26. Pluta, R.; Ułamek, M.; Jabłoński, M. Alzheimer's mechanisms in ischemic brain degeneration. Anat. Rec. 2009, $292,1863-1881$. [CrossRef]

27. Pluta, R.; Januszewski, S.; Jabłoński, M.; Ułamek, M. Factors in creepy delayed neuronal death in hippocampus following brain ischemia-reperfusion injury with long-term survival. Acta Neurochir. 2010, 106, 37-41.

28. Pluta, R.; Ułamek, M.; Jabłoński, M. Consideration of the ischaemic basis and treatment of Alzheimer's disease. Folia Neuropathol. 2010, 48, 11-26. [PubMed]

29. Pluta, R.; Kida, E.; Lossinsky, A.S.; Golabek, A.A.; Mossakowski, M.J.; Wisniewski, H.M. Complete cerebral ischemia with short-term survival in rats induced by cardiac arrest. I. Extracellular accumulation of Alzheimer's $\beta$-amyloid protein precursor in the brain. Brain Res. 1994, 649, 323-328. [CrossRef] 
30. Lee, P.H.; Bang, O.Y.; Hwang, E.M.; Lee, J.S.; Joo, U.S.; Mook-Jung, I.; Huh, K. Circulating beta amyloid protein is elevated in patients with acute ischemic stroke. J. Neural. Transm. 2005, 112, 1371-1379. [CrossRef]

31. Van Groen, T.; Puurunen, K.; Maki, H.M.; Sivenius, J.; Jolkkonen, J. Transformation of diffuse beta-amyloid precursor protein and beta-amyloid deposits to plaques in the thalamus after transient occlusion of the middle cerebral artery in rats. Stroke 2005, 36, 1551-1556. [CrossRef] [PubMed]

32. Qi, J.; Wu, H.; Yang, Y.; Wand, D.; Chen, Y.; Gu, Y.; Liu, T. Cerebral ischemia and Alzheimer's disease: The expression of amyloid- $\beta$ and apolipoprotein E in human hippocampus. J. Alzheimer's Dis. 2007, 12, 335-341. [CrossRef]

33. Zetterberg, H.; Mörtberg, E.; Song, L.; Chang, L.; Provuncher, G.K.; Patel, P.P.; Ferrell, E.; Fournier, D.R.; Kan, C.W.; Campbell, T.G.; et al. Hypoxia due to cardiac arrest induces a time-dependent increase in serum amyloid $\beta$ levels in humans. PLoS ONE 2011, 6, e28263. [CrossRef]

34. Liu, Y.H.; Cao, H.Y.; Wang, Y.R.; Jiao, S.S.; Bu, X.L.; Zeng, F.; Wang, Q.H.; Li, J.; Deng, J.; Zhou, H.D.; et al. Serum A $\beta$ is predictive for short-term neurological deficits after acute ischemic stroke. Neurotox. Res. 2015, 27, 292-299. [CrossRef]

35. Kato, T.; Hirano, A.; Katagiri, T.; Sasaki, H.; Yamada, S. Neurofibrillary tangle formation in the nucleus basalis of Meynert ipsilateral to a massive cerebral infarct. Ann. Neurol. 1988, 23, 620-623. [CrossRef]

36. Hesse, C.; Rosengren, L.; Andreasen, N.; Davidsson, P.; Vanderstichele, H.; Vanmechelen, E.; Blennow, K. Transient increase in total tau but not phospho-tau in human cerebrospinal fluid after acute stroke. Neurosci. Lett. 2001, 297, 187-190. [CrossRef]

37. Bitsch, A.; Horn, C.; Kemmling, Y.; Seipelt, M.; Hellenbrand, U.; Stiefel, M.; Ciesielczyk, B.; Cepek, L.; Bahn, E.; Ratzka, P.; et al. Serum tau protein level as a marker of axonal damage in acute ischemic stroke. Eur. Neurol. 2002, 47, 45-51. [CrossRef] [PubMed]

38. Wunderlich, M.T.; Lins, H.; Skalej, M.; Wallesch, C.W.; Goertler, M. Neuron-specific enolase and tau protein as neurobiochemical markers of neuronal damage are related to early clinical course and long-term outcome in acute ischemic stroke. Clin. Neurol. Neurosurg. 2006, 108, 558-563. [CrossRef]

39. Wen, Y.; Yang, S.H.; Liu, R.; Perez, E.J.; Brun-Ziukemagel, A.M.; Koulen, P.; Simpkins, J.W. Cdk5 is involved in NFT-like tauopathy induced by transient cerebral ischemia in female rats. Biochim. Biophys. Acta 2007, 1772, 473-483. [CrossRef] [PubMed]

40. Kurzepa, J.; Bielewicz, J.; Grabarska, A.; Stelmasiak, Z.; Stryjecka-Zimmer, M.; Bartosik-Psujek, H. Matrix metalloproteinase-9 contributes to the increase of tau protein in serum during acute ischemic stroke. J. Clin. Neurosci. 2010, 17, 997-999. [CrossRef] [PubMed]

41. Bielewicz, J.; Kurzepa, J.; Czekajska-Chehab, E.; Stelmasiak, Z.; Bartosik-Psujek, H. Does serum tau protein predict the outcome of patients with ischemic stroke? J. Mol. Neurosci. 2011, 43, 241-245. [CrossRef] [PubMed]

42. Mörtberg, E.; Zetterberg, H.; Nordmark, J.; Blennow, K.; Catry, C.; Decraemer, H.; Vanmechelen, E.; Rubertsson, S. Plasma tau protein in comatose patients after cardiac arrest treated with therapeutic hypothermia. Acta Anaesthesiol. Scand. 2011, 55, 1132-1138. [CrossRef] [PubMed]

43. Randall, J.; Mörtberg, E.; Provuncher, G.K.; Fournier, D.R.; Duffy, D.C.; Rubertsson, S.; Blennow, K.; Zetterberg, H.; Wilson, D.H. Tau proteins in serum predict neurological outcome after hypoxic brain injury from cardiac arrest: Results of a pilot study. Resuscitation 2013, 84, 351-356. [CrossRef]

44. Lasek-Bal, A.; Jedrzejowska-Szypulka, H.; Rozycka, J.; Bal, W.; Kowalczyk, A.; Holecki, M.; Dulawa, J.; Lewin-Kowalik, J. The presence of tau protein in blood as a potential prognostic factor in stroke patients. J. Physiol. Pharmacol. 2016, 67, 691-696.

45. Majd, S.; Power, J.H.; Koblar, S.A.; Grantham, H.J. Early glycogen synthase kinase-3 and protein phosphatase 2A independent tau dephosphorylation during global brain ischaemia and reperfusion following cardiac arrest and the role of the adenosine monophosphate kinase pathway. Eur. J. Neurosci. 2016, 44, 1987-1997. [CrossRef]

46. Bi, M.; Gladbach, A.; van Eersel, J.; Ittner, A.; Przybyla, M.; van Hummel, A.; Chua, S.W.; van der Hoven, J.; Lee, W.S.; Müller, J.; et al. Tau exacerbates excitotoxic brain damage in an animal model of stroke. Nat. Commun. 2017, 8, 473. [CrossRef]

47. De Vos, A.; Bjerke, M.; Brouns, R.; De Roeck, N.; Jacobs, D.; Van den Abbeele, L.; Guldolf, K.; Zetterberg, H.; Blennow, K.; Engelborghs, S.; et al. Neurogranin and tau in cerebrospinal fluid and plasma of patients with acute ischemic stroke. BMC Neurol. 2017, 17, 170. [CrossRef] [PubMed]

48. Fujii, H.; Takahashi, T.; Mukai, T.; Tanaka, S.; Hosomi, N.; Maruyama, H.; Sakai, N.; Matsumoto, M. Modifications of tau protein after cerebral ischemia and reperfusion in rats are similar to those occurring in Alzheimer's disease-Hyperphosphorylation and cleavage of 4- and 3-repeat tau. J. Cereb. Blood Flow Metab. 2017, 37, 2441-2457. [CrossRef]

49. Khan, S.; Yuldasheva, N.Y.; Batten, T.F.C.; Pickles, A.R.; Kellett, K.A.B.; Saha, S. Tau pathology and neurochemical changes associated with memory dysfunction in an optimized murine model of global cerebral ischaemia-A potential model for vascular dementia? Neurochem. Int. 2018, 118, 134-144. [CrossRef]

50. Kovalska, M.; Tothova, B.; Kovalska, L.; Tatarkova, Z.; Kalenska, D.; Tomascova, A.; Adamkov, M.; Lehotsky, J. Association of induced hyperhomocysteinemia with Alzheimer's disease-like neurodegene-ration in rat cortical neurons after global ischemiareperfusion injury. Neurochem. Res. 2018, 43, 1766-1778. [CrossRef] [PubMed]

51. Pluta, R.; Ułamek-Kozioł, M.; Januszewski, S.; Czuczwar, S.J. Tau protein dysfunction after brain ischemia. J. Alzheimer's Dis. 2018, 66, 429-437. [CrossRef]

52. Pluta, R.; Bogucka-Kocka, A.; Ułamek-Kozioł, M.; Bogucki, J.; Czuczwar, S.J. Ischemic tau protein gene induction as an additional key factor driving development of Alzheimer's phenotype changes in CA1 area of hippocampus in an ischemic model of Alzheimer's disease. Pharmacol. Rep. 2018, 70, 881-884. [CrossRef] 
53. Hatsuta, H.; Takao, M.; Nogami, A.; Uchino, A.; Sumikura, H.; Takata, T.; Morimoto, S.; Kanemaru, K.; Adachi, T.; Arai, T.; et al. Tau and TDP-43 accumulation of the basal nucleus of Meynert in individuals with cerebral lobar infarcts or hemorrhage. Acta Neuropathol. Commun. 2019, 7, 49. [CrossRef] [PubMed]

54. Pluta, R.; Czuczwar, S.J.; Januszewski, S.; Jabłoński, M. The many faces of post-ischemic tau protein in brain neurodegeneration of the Alzheimer's disease type. Cells 2021, 10, 2213. [CrossRef]

55. Ułamek-Kozioł, M.; Kocki, J.; Bogucka-Kocka, A.; Petniak, A.; Gil-Kulik, P.; Januszewski, S.; Bogucki, J.; Jabłoński, M.; FurmagaJabłońska, W.; Brzozowska, J.; et al. Dysregulation of autophagy, mitophagy and apoptotic genes in the medial temporal lobe cortex in an ischemic model of Alzheimer's disease. J. Alzheimer's Dis. 2016, 54, 113-121. [CrossRef]

56. Ułamek-Kozioł, M.; Kocki, J.; Bogucka-Kocka, A.; Januszewski, S.; Bogucki, J.; Czuczwar, S.J.; Pluta, R. Autophagy, mitophagy and apoptotic gene changes in the hippocampal CA1 area in a rat ischemic model of Alzheimer's disease. Pharmacol Rep. 2017, 69, 1289-1294. [CrossRef]

57. Ułamek-Kozioł, M.; Czuczwar, S.J.; Kocki, J.; Januszewski, S.; Bogucki, J.; Bogucka-Kocka, A.; Pluta, R. Dysregulation of autophagy, mitophagy, and apoptosis genes in the CA3 region of the hippocampus in the ischemic model of Alzheimer's disease in the rat. J. Alzheimer's Dis. 2019, 72, 1279-1286. [CrossRef] [PubMed]

58. Kocki, J.; Ułamek-Kozioł, M.; Bogucka-Kocka, A.; Januszewski, S.; Jabłoński, M.; Gil-Kulik, P.; Brzozowska, J.; Petniak, A.; Furmaga-Jabłońska, W.; Bogucki, J.; et al. Dysregulation of amyloid precursor protein, $\beta$-secretase, presenilin 1 and 2 genes in the rat selectively vulnerable CA1 subfield of hippocampus following transient global brain ischemia. J. Alzheimer's Dis. 2015, 47, 1047-1056. [CrossRef]

59. Pluta, R.; Kocki, J.; Ułamek-Kozioł, M.; Petniak, A.; Gil-Kulik, P.; Januszewski, S.; Bogucki, J.; Jabłoński, M.; Brzozowska, J.; Furmaga-Jabłońska, W.; et al. Discrepancy in expression of $\beta$-secretase and amyloid- $\beta$ protein precursor in Alzheimer-related genes in the rat medial temporal lobe cortex following transient global brain ischemia. J. Alzheimer's Dis. 2016, 51, 1023-1031. [CrossRef] [PubMed]

60. Pluta, R.; Ułamek-Kozioł, M.; Kocki, J.; Bogucki, J.; Januszewski, S.; Bogucka-Kocka, A.; Czuczwar, S.J. Expression of the tau protein and amyloid protein precursor processing genes in the CA3 area of the hippocampus in the ischemic model of Alzheimer's disease in the rat. Mol. Neurobiol. 2020, 57, 1281-1290. [CrossRef]

61. Herson, P.S.; Traystman, R.J. Animal models of stroke: Translational potential at present and in 2050. Future Neurol. 2014, 9 , 541-551. [CrossRef]

62. Aggarwal, B.B.; Sundaram, C.; Malani, N.; Ichikawa, H. Curcumin: The Indian solid gold. Adv. Exp. Med. Biol. 2007, 595, 1-75. [PubMed]

63. Ułamek-Kozioł, M.; Czuczwar, S.J.; Januszewski, S.; Pluta, R. Substantiation for the use of curcumin during the development of neurodegeneration after brain ischemia. Int. J. Mol. Sci. 2020, 21, 517. [CrossRef] [PubMed]

64. Peterson, C.T.; Vaughn, A.R.; Sharma, V.; Chopra, D.; Mills, P.J.; Peterson, S.N.; Sivamani, R.K. Effects of turmeric and curcumin dietary supplementation on human gut microbiota: A double-blind, randomized, placebo-controlled pilot study. J. Evid.-Based Integr. Med. 2018, 23, 2515690X18790725. [CrossRef] [PubMed]

65. Thiyagarajan, M.; Sharma, S.S. Neuroprotective effect of curcumin in middle cerebral artery occlusion induced focal cerebral ischemia in rats. Life Sci. 2004, 74, 969-985. [CrossRef]

66. Jiang, J.; Wang, W.; Sun, Y.J.; Hu, M.; Li, F.; Zhu, D.Y. Neuroprotective effect of curcumin on focal cerebral ischemic rats by preventing blood-brain barrier damage. Eur. J. Pharmacol. 2007, 561, 54-62. [CrossRef]

67. Dohare, P.; Garg, P.; Jain, V.; Nath, C.; Ray, M. Dose dependence and therapeutic window for the neuroprotective effects of curcumin in thromboembolic model of rat. Behav. Brain Res. 2008, 193, 289-297. [CrossRef]

68. Zhao, J.; Yu, S.; Zheng, W.; Feng, G.; Luo, G.; Wang, L.; Zhao, Y. Curcumin improves outcomes and attenuates focal cerebral ischemic injury via antiapoptotic mechanisms in rats. Neurochem. Res. 2010, 35, 374-379. [CrossRef]

69. Tyagi, N.; Qipshidze, N.; Munjal, C.; Vacek, J.C.; Metreveli, N.; Givvimani, S.; Tyagi, S.C. Tetrahydrocurcumin ameliorates homocysteinylated cytochrome-c mediated autophagy in hyperhomocysteinemia mice after cerebral ischemia. J. Mol. Neurosci. 2012, 47, 128-138. [CrossRef]

70. Funk, J.L.; Frye, J.B.; Davis-Gorman, G.; Spera, A.L.; Bernas, M.J.; Witte, M.H.; Weinand, M.E.; Timmermann, B.N.; McDonagh, P.F.; Ritter, L. Curcuminoids limit neutrophil-mediated reperfusion injury in experimental stroke by targeting the endothelium. Microcirculation 2013, 20, 544-554. [CrossRef]

71. Kelly-Cobbs, A.I.; Prakash, R.; Li, W.; Pillai, B.; Hafez, S.; Coucha, M.; Johnson, M.H.; Ogbi, S.N.; Fagan, S.C.; Ergul, A. Targets of vascular protection in acute ischemic stroke differ in type 2 diabetes. Am. J. Physiol. Heart Circ. Physiol. 2013, 304, H806-H815. [CrossRef]

72. Kalani, A.; Chaturvedi, P.; Kamat, P.K.; Maldonado, C.; Bauer, P.; Joshua, I.G.; Tyagi, S.C.; Tyagi, N. Curcumin-loaded embryonic stem cell exosomes restored neurovascular unit following ischemia-reperfusion injury. Int. J. Biochem. Cell Biol. 2016, 79, 360-369. [CrossRef]

73. Miao, Y.; Zhao, S.; Gao, Y.; Wang, R.; Wu, Q.; Wu, H.; Luo, T. Curcumin pretreatment attenuates inflammation and mitochondrial dysfunction in experimental stroke: The possible role of Sirt1 signaling. Brain Res. Bull. 2016, 121, 9-15. [CrossRef]

74. Shah, F.A.; Gim, S.A.; Sung, J.H.; Jeon, S.J.; Kim, M.O.; Koh, P.O. Identification of proteins regulated by curcumin in cerebral ischemia. J. Surg. Res. 2016, 201, 141-148. [CrossRef] 
75. Zhang, Y.; Yan, Y.; Cao, Y.; Yang, Y.; Zhao, Q.; Jing, R.; Jing, R.; Hu, J.; Bao, J. Potential therapeutic and protective effect of curcumin against stroke in the male albino stroke-induced model rats. Life Sci. 2017, 183, 45-49. [CrossRef]

76. Huang, L.; Chen, C.; Zhang, X.; Li, X.; Chen, Z.; Yang, C.; Liang, X.; Zhu, G.; Xu, Z. Neuroprotective effect of curcumin against cerebral ischemia-reperfusion via mediating autophagy and inflammation. J. Mol. Neurosci. 2018, 64, 129-139. [CrossRef] [PubMed]

77. Xia, M.; Ye, Z.; Shi, Y.; Zhou, L.; Hua, Y. Curcumin improves diabetes mellitus associated cerebral infarction by increasing the expression of GLUT1 and GLUT3. Mol. Med. Rep. 2018, 17, 1963-1969. [CrossRef]

78. Zhang, Y.; Fang, M.; Sun, Y.; Zhang, T.; Shi, N.; Li, J.; Jin, L.; Liu, K.; Fu, J. Curcumin attenuates cerebral ischemia injury in sprague-dawley rats and PC12 cells by suppressing overactivated autophagy. J. Photochem. Photobiol. B 2018, 184, 1-6. [CrossRef] [PubMed]

79. Wang, Q.; Sun, A.Y.; Simonyi, A.; Jensen, M.D.; Shelat, P.B.; Rottinghaus, G.E.; MacDonald, R.S.; Miller, D.K.; Lubahn, D.E.; Weisman, G.A.; et al. Neuroprotective mechanisms of curcumin against cerebral ischemia-induced neuronal apoptosis and behavioral deficits. J. Neurosci. Res. 2005, 82, 138-148. [CrossRef] [PubMed]

80. Altinay, S.; Cabalar, M.; Isler, C.; Yildirim, F.; Celik, D.S.; Zengi, O.; Tas, A.; Gulcubuk, A. Is chronic curcumin supplementation neuroprotective against ischemia for antioxidant activity, neurological deficit, or neuronal apoptosis in an experimental stroke model? Turk. Neurosurg. 2017, 27, 537-545.

81. Mukherjee, A.; Sarkar, S.; Jana, S.; Swarnakar, S.; Das, N. Neuro-protective role of nanocapsulated curcumin against cerebral ischemia-reperfusion induced oxidative injury. Brain Res. 2019, 1704, 164-173. [CrossRef]

82. Li, Y.; Li, J.; Li, S.; Wang, X.; Liu, B.; Fu, Q.; Ma, S. Curcumin attenuates glutamate neurotoxicity in the hippocampus by suppression of ER stress-associated TXNIP/NLRP3 inflammasome activation in a manner dependent on AMPK. Toxicol. Appl. Pharmacol. 2015, 286, 53-63. [CrossRef]

83. Hou, Y.; Wang, J.; Feng, J. The neuroprotective effects of curcumin are associated with the regulation of the reciprocal function between autophagy and HIF-1 $\alpha$ in cerebral ischemia-reperfusion injury. Drug Des. Dev. Ther. 2019, 13, 1135-1144. [CrossRef] [PubMed]

84. Liu, W.; Zhai, Y.; Heng, X.; Che, F.Y.; Chen, W.; Sun, D.; Zhai, G. Oral bioavailability of curcumin: Problems and advancements. J. Drug Target. 2016, 24, 694-702. [CrossRef] [PubMed]

85. Liu, S.; Cao, Y.; Qu, M.; Zhang, Z.; Feng, L.; Ye, Z.; Xiao, M.; Hou, S.T.; Zheng, R.; Han, Z. Curcumin protects against stroke and increases levels of Notch intracellular domain. Neurol. Res. 2016, 38, 553-559. [CrossRef]

86. Zhang, Z.; Chen, Y.; Xiang, L.; Wang, Z.; Xiao, G.G.; Hu, J. Effect of curcumin on the diversity of gut microbiota in ovariectomized rats. Nutrients 2017, 9, 1146. [CrossRef] [PubMed]

87. Lan, C.; Chen, X.; Zhang, Y.; Wang, W.; Wang, W.E.; Liu, Y.; Cai, Y.; Ren, H.; Zheng, S.; Zhou, L.; et al. Curcumin prevents strokes in stroke-prone spontaneously hypertensive rats by improving vascular endothelial function. BMC Cardiovasc. Disord. 2018, 18, 43. [CrossRef]

88. Xie, C.J.; Gu, A.P.; Cai, J.; Wu, Y.; Chen, R.C. Curcumin protects neural cells against ischemic injury in N2a cells and mouse brain with ischemic stroke. Brain Behav. 2018, 8, e00921. [CrossRef] [PubMed]

89. Li, W.; Suwanwela, N.C.; Patumraj, S. Curcumin by down-regulating NF-kB and elevating Nrf2, reduces brain edema and neurological dysfunction after cerebral I/R. Microvasc. Res. 2016, 106, 117-127. [CrossRef]

90. Jia, G.; Tan, B.; Ma, J.; Zhang, L.; Jin, X.; Li, C. Prdx6 upregulation by curcumin attenuates ischemic oxidative damage via SP1 in rats after stroke. BioMed Res. Int. 2017, 2017, 6597401. [CrossRef]

91. Yan, R.; Vassar, R. Targeting the beta secretase BACE1 for Alzheimer's disease therapy. Lancet Neurol. 2014, 13, 319-329. [CrossRef]

92. Yang, F.; Lim, G.P.; Begum, A.N.; Ubeda, O.J.; Simmons, M.R.; Ambegaokar, S.S.; Chen, P.P.; Kayed, R.; Glabe, C.G.; Frautschy, S.A.; et al. Curcumin inhibits formation of amyloid beta oligomers and fibrils, binds plaques, and reduces amyloid in vivo. J. Biol. Chem. 2005, 280, 5892-5901. [CrossRef] [PubMed]

93. Cole, G.M.; Teter, B.; Frautschy, S.A. Neuroprotective effects of curcumin. Adv. Exp. Med. Biol. 2007, 595, 197-212. [PubMed]

94. Narlawar, R.; Baumann, K.; Schubenel, R.; Schmidt, B. Curcumin derivatives inhibit or modulate beta-amyloid precursor protein metabolism. Neurodegener. Dis. 2007, 4, 88-93. [CrossRef] [PubMed]

95. Zhang, C.; Browne, A.; Child, D.; Tanzi, R.E. Curcumin decreases amyloid- $\beta$ peptide levels by attenuating the maturation of amyloid- $\beta$ precursor protein. J. Biol. Chem. 2010, 285, 28472-28480. [CrossRef]

96. Huang, H.C.; Xu, K.; Jiang, Z.F. Curcumin-mediated neuroprotection against amyloid-beta-induced mitochondrial dysfunction involves the inhibition of GSK-3beta. J. Alzheimer's Dis. 2012, 32, 981-996. [CrossRef] [PubMed]

97. Huang, X.; Atwood, C.S.; Moir, R.D.; Hartshorn, M.A.; Tanzi, R.E.; Bush, A.I. Trace metal contamination initiates the apparent auto-aggregation, amyloidosis, and oligomerization of Alzheimer's A $\beta$ peptides. J. Biol. Inorg. Chem. 2004, 9, 954-960. [CrossRef]

98. Masuda, Y.; Fukuchi, M.; Yatagawa, T.; Tada, M.; Takeda, K.; Irie, K.; Akagi, K.-I.; Monobe, Y.; Imazawa, T.; Takegoshi, K. Solid-state NMR analysis of interaction sites of curcumin and 42-residue amyloid $\beta$-protein fibrils. Bioorganic Med. Chem. 2011, 19, 5967-5974. [CrossRef]

99. Kim, H.; Park, B.S.; Lee, K.G.; Choi, C.Y.; Jang, S.S.; Kim, Y.H.; Lee, S.E. Effects of naturally occurring compounds on fibril formation and oxidative stress of beta-amyloid. J. Agric. Food Chem. 2005, 53, 8537-8541. [CrossRef]

100. Feng, H.L.; Fan, H.; Dang, H.Z.; Chen, X.P.; Ren, Y.; Yang, J.D.; Wang, P.W. Neuroprotective effect of curcumin to Abeta of double transgenic mice with Alzheimer's disease. J. Chin. Mater. Med. 2014, 39, 3846-3849. 
101. Hu, S.; Maiti, P.; Ma, Q.; Zuo, X.; Jones, M.R.; Cole, G.M.; Frautschy, S.A. Clinical development of curcumin in neurodegenerative disease. Expert Rev. Neurother. 2015, 15, 629-637. [CrossRef]

102. Koronyo, Y.; Biggs, D.; Barron, E.; Boyer, D.S.; Pearlman, J.A.; Au, W.J.; Kile, S.J.; Blanco, A.; Fuchs, D.T.; Ashfaq, A.; et al. Retinal amyloid pathology and proof-of-concept imaging trial in Alzheimer's disease. JCI Insight 2017, 2, e93621. [CrossRef] [PubMed]

103. Ono, K.; Hasegawa, K.; Naiki, H.; Yamada, M. Curcumin has potent anti amyloidogenic effects for Alzheimer's beta-amyloid fibrils in vitro. J. Neurosci. Res. 2004, 75, 742-750. [CrossRef] [PubMed]

104. Mishra, S.; Palanivelu, K. The effect of curcumin (turmeric) on Alzheimer's disease: An overview. Ann. Indian Acad. Neurol. 2008, 11, 13-19. [CrossRef] [PubMed]

105. Thapa, A.; Jett, S.D.; Chi, E.Y. Curcumin attenuates amyloid- $\beta$ aggregate toxicity and modulates amyloid- $\beta$ aggregation pathway. ACS Chem. Neurosci. 2015, 7, 56-68. [CrossRef]

106. Brahmkhatri, V.; Sharma, N.; Punnepalli, S.; D'Souza, A.; Raghothama, S.; Atreya, H.S. Curcumin nanoconjugate inhibits aggregation of N-terminal region (A $\beta-16)$ of an amyloid beta peptide. N. J. Chem. 2018, 42, 19881-19892. [CrossRef]

107. Mithu, V.S.; Sarkar, B.; Bhowmik, D.; Das, A.K.; Chandrakesan, M. Curcumin alters the salt bridge-containing turn region in amyloid $\beta$ (1-42) aggregates. J. Biol. Chem. 2014, 289, 11122-11131. [CrossRef]

108. Garcia-Alloza, M.; Borrelli, L.A.; Rozkalne, A.; Hyman, B.T.; Bacskai, B.J. Curcumin labels amyloid pathology in vivo, disrupts existing plaques, and partially restores distorted neurites in an Alzheimer mouse model. J. Neurochem. 2007, 102, 1095-1104. [CrossRef]

109. Thal, D.R. Clearance of amyloid beta-protein and its role in the spreading of Alzheimer's disease pathology. Front. Aging Neurosci. 2015, 7, 25. [CrossRef]

110. Frautschy, S.A.; Hu, W.; Kim, P.; Miller, S.A.; Chu, T.; Harris-White, M.E.; Cole, G.M. Phenolic anti-inflammatory antioxidant reversal of Abeta-induced cognitive deficits and neuropathology. Neurobiol. Aging 2001, 22, 993-1005. [CrossRef]

111. Cole, G.M.; Morihara, T.; Lim, G.P.; Yang, F.; Begum, A.; Frautschy, S.A. NSAID and antioxidant prevention of Alzheimer's disease: Lessons from in vitro and animal models. Ann. N. Y. Acad. Sci. 2004, 1035, 68-84. [CrossRef]

112. Maiti, P.; Dunbar, G.L. Use of curcumin, a natural polyphenol for targeting molecular pathways in treating age-related neurodegenerative diseases. Int. J. Mol. Sci. 2018, 19, 1637. [CrossRef] [PubMed]

113. Wen, Y.; Yang, S.; Liu, R.; Simpkins, J.W. Transient cerebral ischemia induces site-specific hyperphosphorylation of tau protein. Brain Res. 2004, 1022, 30-38. [CrossRef] [PubMed]

114. Wen, Y.; Yang, S.; Liu, R.; Brun-Zinkernagel, A.M.; Koulen, P.; Simpkins, J.W. Transient cerebral ischemia induces aberrant neuronal cell cycle re-entry and Alzheimer's disease-like tauopathy in female rats. J. Biol. Chem. 2004, 279, 22684-22692. [CrossRef] [PubMed]

115. Pluta, R.; Januszewski, S.; Czuczwar, S.J. Brain ischemia as a prelude to Alzheimer's disease. Front. Aging Neurosci. 2021, 13, 636653. [CrossRef]

116. Mondragon-Rodriguez, S.; Perry, G.; Zhu, X.; Moreira, P.I.; Acevedo-Aquino, M.C.; Williams, S. Phosphorylation of tau protein as the link between oxidative stress, mitochondrial dysfunction, and connectivity failure: Implications for Alzheimer's disease. Oxidative Med. Cell. Longev. 2013, 2013, 940603. [CrossRef]

117. Stoothoff, W.H.; Johnson, G.V. Tau phosphorylation: Physiological and pathological consequences. Biochim. Biophys. Acta 2005, 1739, 280-297. [CrossRef]

118. Caughey, B.; Raymond, L.D.; Raymond, G.J.; Maxson, L.; Silveira, J.; Baron, G.S. Inhibition of protease-resistant prion protein accumulation in vitro by curcumin. J. Virol. 2003, 77, 5499-5502. [CrossRef]

119. Rane, J.S.; Bhaumik, P.; Panda, D. Curcumin inhibits tau aggregation and disintegrates preformed tau filaments in vitro. J. Alzheimer's Dis. 2017, 60, 999-1014. [CrossRef]

120. Ma, Q.L.; Zuo, X.; Yang, F.; Ubeda, O.J.; Gant, D.J.; Alaverdyan, M.; Teng, E.; Hu, S.; Chen, P.P.; Maiti, P.; et al. Curcumin suppresses soluble tau dimers and corrects molecular chaperone, synaptic, and behavioral deficits in aged human tau transgenic mice. J. Biol. Chem. 2013, 288, 4056-4065. [CrossRef]

121. Ireson, C.R.; Jones, D.J.; Orr, S.; Coughtrie, M.W.; Boocock DJWilliams, M.L.; Farmer, P.B.; Steward, W.P.; Gescher, A.J. Metabolism of the cancer chemopreventive agent curcumin in human and rat intestine. Cancer Epidemiol. Prev. Biomark. 2002, 11, $105-111$.

122. Marczylo, T.H.; Verschoyle, R.D.; Cooke, D.N.; Morazzoni, P.; Steward, W.P.; Gescher, A.J. Comparison of systemic availability of curcumin with that of curcumin formulated with phosphatidylcholine. Cancer Chemother. Pharmacol. 2007, 60, 171-177. [CrossRef] [PubMed]

123. Sharma, R.A.; Steward, W.P.; Gescher, A.J. Pharmacokinetics and pharmacodynamics of curcumin. Adv. Exp. Med. Biol. 2007, 595, 453-470.

124. Srinivasan, K. Black pepper and its pungent principle-piperine: A review of diverse physiological effects. Crit. Rev. Food Sci. Nutr. 2007, 47, 735-748. [CrossRef] [PubMed]

125. Teymouri, M.; Barati, N.; Pirro, M.; Sahebkar, A. Biological and pharmacological evaluation of dimethoxycurcumin: A metabolically stable curcumin analogue with a promising therapeutic potential. J. Cell. Physiol. 2018, 233, 124-140. [CrossRef] [PubMed]

126. Calabrese, E.J. Hormesis: From mainstream to therapy. J. Cell Commun. Signal. 2014, 8, 289-291. [CrossRef]

127. Bielak-Zmijewska, A.; Grabowska, W.; Ciolko, A.; Bojko, A.; Mosieniak, G.; Bijoch, Ł.; Sikora, E. The role of curcumin in the modulation of ageing. Int. J. Mol. Sci. 2019, 20, 1239. [CrossRef] 
128. Anand, P.; Kunnumakkara, A.B.; Newman, R.A.; Aggarwal, B.B. Bioavailability of curcumin: Problems and promises. Mol. Pharm. 2007, 4, 807-818. [CrossRef]

129. Vareed, S.K.; Kakarala, M.; Ruffin, M.T.; Crowell, J.A.; Normolle, D.P.; Djuric, Z.; Brenner, D.E. Pharmacokinetics of curcumin conjugate metabolites in healthy human subjects. Cancer Epidemiol. Biomark. Prev. 2008, 17, 1411-1417. [CrossRef]

130. Szymusiak, M.; Hu, X.; Leon Plata, P.A.; Ciupinski, P.; Wang, Z.J.; Liu, Y. Bioavailability of curcumin and curcumin glucuronide in the central nervous system of mice after oral delivery of nano-curcumin. Int. J. Pharm. 2016, 511, 415-423. [CrossRef]

131. Sasaki, H.; Sunagawa, Y.; Takahashi, K.; Imaizumi, A.; Fukuda, H.; Hashimoto, T.; Wada, H.; Katanasaka, Y.; Kakeya, H.; Fujita, M.; et al. Innovative preparation of curcumin for improved oral bioavailability. Biol. Pharm. Bull. 2011, 34, 660-665. [CrossRef]

132. Kanai, M.; Imaizumi, A.; Otsuka, Y.; Sasaki, H.; Hashiguchi, M.; Tsujiko, K.; Matsumoto, S.; Ishiguro, H.; Chiba, T. Dose-escalation and pharmacokinetic study of nanoparticle curcumin, a potential anticancer agent with improved bioavailability, in healthy human volunteers. Cancer Chemother. Pharmacol. 2012, 69, 65-70. [CrossRef]

133. Peyrol, J.; Meyer, G.; Obert, P.; Dangles, O.; Pechere, L.; Amiot, M.J.; Riva, C. Involvement of bilitranslocase and beta-glucuronidase in the vascular protection by hydroxytyrosol and its glucuronide metabolites in oxidative stress conditions. J. Nutr. Biochem. 2018, 51, 8-15. [CrossRef] [PubMed]

134. Slevin, M.; Capitanescu, B.; Sanfeliu, C.; Zeinolabediny, Y.; AlBaradie, R.; Olah, P.; Guo, B.; Pirici, D.; Napoli, M.D.; Popa-Wagner A. Monomeric $\mathrm{C}$-reactive protein aggravates secondary degeneration after intracerebral haemorrhagic stroke and may function as a sensor for systemic inflammation. J. Clin. Med. 2020, 9, 3053. [CrossRef]

135. Mukkavilli, R.; Yang, C.; Tanwar, R.S.; Saxena, R.; Gundala, S.R.; Zhang, Y.; Ghareeb, A.; Floyd, S.D.; Vangala, S.; Kuo, W.W.; et al. Pharmacokinetic-pharmacodynamic correlations in the development of ginger extract as an anticancer agent. Sci. Rep. 2018, 8, 3056. [CrossRef]

136. Tsai, Y.M.; Chien, C.F.; Lin, L.C.; Tsai, T.H. Curcumin and its nano-formulation: The kinetics of tissue distribution and blood-brain barrier penetration. Int. J. Pharm. 2011, 416, 331-338. [CrossRef] [PubMed]

137. Yuan, J.; Liu, W.; Zhu, H.; Zhang, X.; Feng, Y.; Chen, Y.; Feng, H.; Lin, J. Curcumin attenuates blood-brain barrier disruption after subarachnoid hemorrhage in mice. J. Surg. Res. 2017, 207, 85-91. [CrossRef]

138. Tomas-Barberan, F.A.; Selma, M.V.; Espin, J.C. Interactions of gut microbiota with dietary polyphenols and consequences to human health. Curr. Opin. Clin. Nutr. Metab. Care 2016, 19, 471-476. [CrossRef] [PubMed]

139. Zam, W. Gut microbiota as a prospective therapeutic target for curcumin: A review of mutual influence. J. Nutr. Metab. 2018, 2018, 1367984. [CrossRef] [PubMed]

140. McIntosh, F.M.; Maison, N.; Holtrop, G.; Young, P.; Stevens, V.J.; Ince, J.; Johnstone, A.M.; Lobley, G.E.; Flint, H.J.; Louis, P. Phylogenetic distribution of genes encoding $\beta$-glucuronidase activity in human colonic bacteria and the impact of diet on faecal glycosidase activities. Environ. Microbiol. 2012, 14, 1876-1887. [CrossRef]

141. O'Toole, P.W.; Jeffery, I.B. Gut microbiota and aging. Science 2015, 350, 1214-1215. [CrossRef]

142. Battaglini, D.; Pimentel-Coelho, P.M.; Robba, C.; Dos Santos, C.C.; Cruz, F.F.; Pelosi, P.; Rocco, P.R.M. Gut microbiota in acute ischemic stroke: From pathophysiology to therapeutic implications. Front. Neurol. 2020, 11, 598. [CrossRef] [PubMed]

143. Bonsack, B.; Jiang, R.H.; Borlongan, C.V. A gut feeling about stroke reveals gut-brain axis' active role in homeostasis and dysbiosis. J. Cereb. Blood Flow Metab. 2020, 40, 1132-1134. [CrossRef] [PubMed]

144. Holmes, A.; Finger, C.; Morales-Scheihing, D.; Lee, J.; McCullough, L.D. Gut dysbiosis and age-related neurological diseases; an innovative approach for therapeutic interventions. Transl. Res. 2020, 226, 39-56. [CrossRef]

145. Liu, J.; Zhang, T.; Wang, Y.; Si, C.; Wang, X.; Wang, R.T.; Lv, Z. Baicalin ameliorates neuropathology in repeated cerebral ischemia-reperfusion injury model mice by remodeling the gut microbiota. Aging (Albany NY) 2020, 12, 3791-3806. [CrossRef] [PubMed]

146. Ohno, M.; Nishida, A.; Sugitani, Y.; Nishino, K.; Inatomi, O.; Sugimoto, M.; Kawahara, M.; Andoh, A. Nanoparticle curcumin ameliorates experimental colitis via modulation of gut microbiota and induction of regulatory T cells. PLoS ONE 2017, 12, e0185999. [CrossRef] [PubMed]

147. Shen, L.; Liu, L.; Ji, H.-F. Regulative effects of curcumin spice administration on gut microbiota and its pharmacological implications. Food Nutr. Res. 2017, 61, 1361780. [CrossRef] [PubMed]

148. Chen, Y.M.; Chiu, W.C.; Chiu, Y.S.; Li, T.; Sung, H.C.; Hsiao, C.Y. Supplementation of nano-bubble curcumin extract improves gut microbiota composition and exercise performance in mice. Food Funct. 2020, 11, 3574-3584. [CrossRef]

149. Scazzocchio, B.; Minghetti, L.; D'Archivio, M. Interaction between gut microbiota and curcumin: A new key of understanding for the health effects of curcumin. Nutrients 2020, 12, E2499. [CrossRef]

150. Fîlfan, M.; Sandu, R.E.; Zăvăleanu, A.D.; Greşită, A.; Glăvan, D.G.; Olaru, D.G.; Popa-Wagner, A. Autophagy in aging and disease. Rom. J. Morphol. Embryol. 2017, 58, 27-31. 